\title{
An Evaluation of One Day Science Activities at a Natural History Museum
}

\section{Doğa Tarihi Müzesinde Bir Günlük Fen Etkinliklerinin Değerlendirilmesi}

\author{
Ayşegül EVREN-YAPICIOĞLU* (i) Kalender ARIKAN** \\ Aydın AKBULUT
}

Received: 17 March 2021

Research Article

Accepted: 10 August 2021

ABSTRACT: This study investigated the evaluation of science activities held over one day at the natural history museum (NHM) in a rural part of Turkey. The purpose of the research was to determine one day science activities in NHM through students' expectations, observations, feelings, learning experiences, and their effect on their academic achievement and explore teachers' views about the process. Middle school students $(n=125)$ and their teachers $(n=8)$ participated the activities. Qualitative dominant (QUAL+quan) parallel convergent design, one of the mixed research methods, was used in the research. Four different data collection tools (achievement test and three semistructured interview forms) were used. According to the results, the activities had a positive effect on the academic achievement of middle school students. It also helped them gain more profound experiences about the components of nature and develop more positive emotions. Prior to the science activities, the students expected to focus on observations and examinations. They emphasized the activities they conducted to collect and analyze fossils more strongly after the completion of activities. Teachers stated that science activities in the museum increased the active participation and interest of the students compared to the classroom environment and enabled them to provide awareness towards the environment and science.

Keywords: Museum education, middle school students and natural science history museum.

ÖZ: Araştırmada Türkiye'nin kırsal kesiminde bulunan bir doğa tarihi müzesinde bir günlük fen etkinlikleri değerlendirilmiştir. Araştırmanın amacı doğa tarihi müzesindeki bir günlük fen etkinlikleri öncesi ve sonrasında öğrencilerin beklentilerini, gözlemlerini, duygularını, öğrenme deneyimleri ile akademik başarılarına etkisini belirlemek ve sürece eşlik eden öğretmenin görüşlerini keşfetmektir. Ortaokul öğrencileri $(n=125)$ ile öğretmenleri $(n=8)$ araştırmaya katılmıştır. Karma araştırma yöntemlerinden nitel baskın statülü $(N I T+n i c)$ yakınsayan paralel desen kullanılmıştır. Dört veri toplama aracı (başarı testi ve üç yarı yapılandırılmış görüşme formu) kullanılmıştır. Elde edilen sonuçlara göre etkinliklerin ortaokul öğrencilerinin akademik başarılarına olumlu etkisi olmuştur. Ayrıca, doğanın bileşenleri hakkında derin deneyimler edinmelerine ve daha olumlu duygular geliştirmelerine katkı sağlamıştır. Müzedeki etkinlikler öncesinde öğrenciler daha çok gözlem ve inceleme odaklı etkinlikler yapacakları beklentisindeyken, etkinlikler sonrasında mikroskopla inceleme, fosil toplama ve analiz etme deneyimlerinden daha sık bahsetmişlerdir. Katılım gösteren öğretmenler ise müzedeki fen etkinliklerinin öğrencilerin sınıf ortamına kıyasla aktif katılımını ve ilgilerini arttırdığı, çevreye ve fene yönelik farkındalık sağladığını belirtmişlerdir.

Anahtar kelimeler: Müze eğitimi, ortaokul öğrencileri ve doğa tarihi müzesi.

\footnotetext{
* Corresponding Author: Dr. Ayşegül Evren-Yapıcığlu, Muğla Sitkı Koçman University, Muğla, Turkey, aevren@mu.edu.tr, https://orcid.org/0000-0003-0528-8528

** Dr. Kalender Arıkan, Hacettepe University, Ankara, Turkey, kalender.a@ gmail.com, https://orcid.org/0000-00029862-9629

*** Prof. Dr. Aydın Akbulut, Hacettepe University, Ankara, Turkey, akbulut1969@gmail.com, https://orcid.org/0000-0002-7604-4435
}

\section{Citation Information}

Evren-Yapıcıoğlu, A., Arıkan, K., \& Akbulut, A. (2021). An evaluation of one day science activities at a natural history museum . Kuramsal Ĕgitimbilim Dergisi [Journal of Theoretical Educational Science], 14(4), 524-547. 
Museums focus on their audiences by designing spaces, programs, and exhibitions that encourage repeat visitors (Anderson et al., 2002). According to the European Group on Museum Statistics (EGMUS, 2020), almost 710 million people visited different types of museums in European countries in 2019. The number of visitors to museums in Turkey was nearly 35 million in the same year (The Ministry of Culture and Tourism, 2020). These numbers show how important museums are for people. Museums showcasing natural history, science, industry, and art are considered tools for visual education as they are devoted to the realization of that educational principle for many years (Klopfer et al., 2005; Melton et al., 1936). Museum education is an applied interdisciplinary field relying on research and methodology derived from psychology, education, sociology, anthropology (Falk \& Dierking, 1992; Rennie \& McClafferty, 1996), and other areas (Koran \& Koran, 1986). As many as 3417 museums in Europe held active special education programs for children in 2019 (EGMUS, 2020). Research on museum education for children in the nineties is extremely limited (Piscitelli \& Anderson, 2001), but the number of studies has increased over the last few decades (Laherto, 2013), with out-of-school oriented learning environments gaining importance (Eshach, 2007).

When the educational literature is reviewed, there are many concepts used by researchers related to educational terminology in the literature of such as formal, informal, non-formal, out-of-school, out-of-class, free-choice, coincidental learning (Atmaca, 2012; Falk, 2005; Hofstein \& Rosenfeld, 1996; Rogoff et al., 2016; Salmi, 1993; Tuan Soh \& Mohd Meerah, 2013). This diversity in conceptualization causes problems in the literature (Hofstein \& Rosenfeld, 1996; Rogoff et al., 2016). Most authors have classified the educational environment of museum as either a form of informal learning (Gerber et al., 2001a, 2001b; Shaby et al., 2016) or non-formal science learning (Eshach, 2007).

Studies on museums or museum education over the decades have provided incompatible results that both support its effectiveness and critique its ineffectiveness. Some researchers (Anderson, 1999; Kubota \& Olstad, 1991) have stated that the highly stimulating and novel physical and social environments that museums provide are linked to ineffective learning, whereas others have argued that visiting a museum can increase interest, academic achievement, permanence of learning and enhance the enjoyment of science and related activities, which constitute extremely valuable learning outcomes (Ayres \& Melear, 1998; Egüz, 2020; Wolins et al., 1992; Yetkiner et al., 2019). The outcomes of museum education persist over time, according to some studies (Dragotto et al., 2006; Falk \& Dierking, 1997; Taylor \& Neill, 2008), while others have emphasized that these outcomes are temporary (Rennie, 1994; Wolins et al., 1992). Although museum education is not rocket science (Dragotto et al., 2006), it is becoming increasingly complex. All research on museum education can be grouped into three categories: research focusing on the affective and social aspects of visitors' experiences; the behaviors of families or other visitors; and education as training activities (Piscitelli \& Anderson, 2001). With the recent digitalization era, virtual reality and mobile museum applications, distance education strategies have come to the fore in museum research (Bontempi \& Smith Nash, 2012; Bulut \& Uzun, 2021; Kasapoğlu Akyol, 2020; Notario Sánchez, 2020; Taranova, 2020;). Such applications have turned distant places into close proximity to all people and impossibilities into possibilities. 
Especially during the COVID 19 Pandemic period, digital applications in museums have gained importance, necessitating the digital participation of the audience in the applications in the museum (Karadeniz, 2020).

Museum education also contributed to enhancing public school students' cognitive learning (Kubota \& Olstad, 1991; Suter, 2014). Post-visit activities enabled seventh-year students to construct and reconstruct their knowledge of the concepts and principles of science (Anderson, 1999). Ayres and Melear (1998) studied elementary school (from 8 to 13 years old) students to compare multimedia and hands-on learning in museums. They found that science learning increased when students interacted with multimedia exhibits as opposed to when they interacted with hands-on exhibits. Martin et al. (2016) demonstrated gains in content knowledge recall, self-efficacy, valuation, and aspirations, and links between these gains and positive beliefs about health practices in a museum-based science education program for elementary and secondary school students (aged 10-16 years). On the other hand, Çıldır (2018), determined that the educational activities in the museum did not make any change in the level of knowledge while improving the writing skills of the eighth-grade students. According to Egüz (2020), it had been revealed that teaching practices based on museum education within the scope of the "Culture and Heritage" unit were effective in increasing the academic achievement of fifth-grade students, reinforcing the subjects and ensuring learning permanence. Similarly, Türkmen (2018) determined that their visit to the Natural History Museum (NHM), which was structured according to the learning cycle, increased fifth-grade students' academic achievement on fossils and made positive statements about the museum.

When the researches of museum visits, activities and programs and were examined; It emphasized that museums, parks, natural habitats and school gardens are not perceived as out-of-school learning environments by teachers and pre-service teachers (Bostan Sarığlan \& Küçüközer, 2017) and these areas were out-of-school learning environments where teachers' responsibility is high (Ay et al., 2015). For this reason, teachers' views, knowledge and attitudes towards museum education or visits are decisive in students' museum visits (Mortensen \& Smart, 2007). Although teachers know the benefits of taking students on museum trips (Cox-Petersen et al., 2003; Griffin, 2004), blending formal classroom learning with museum education can be difficult (Kisiel, 2003). Tal et al. (2005) stated in their research with 30 teachers (serving at the 4th to 10th-grade levels) that they did not know the reason for their museum visit and described the school trip as a fun activity rather than a well-planned educational experience. Thus, teachers' opinions, knowledge, and attitudes toward museum education or visits determine students' museum visits (Mortensen \& Smart, 2007). Solmaz (2015) stated that social studies teachers did not know the concept of museum education and were unaware that its practices had been revealed. According to the author, although all of the teachers participating in the research stated that museum education was essential for the social studies course, it provided permanence in learning, facilitates learning, and provides visual learning, it had been observed that teachers had not taken their students to museum visits recently. Although teachers know the benefits of taking students on field trips to museums (Cox-Petersen et al., 2003; Griffin, 2004), blending formal classroom learning with museum education can be challenging (Kisiel, 2003). 
Over the years, the importance of placing museums in curricula and integrating them with informal learning environments is increasing (Shaby et al., 2016). There are many scientific studies for formal educational institutions such as schools. However, it is very difficult to transfer the findings obtained from the studies conducted in the school environment to environments such as museums that are more complex out-ofschool environments and have a large number of objects, concrete materials such as exhibitions (Andre et al., 2017). In addition, planning and implementing research in a formal environment can be much easier than in environments outside the school. In informal areas such as museums outside the school, the interaction of students with a large number of objects (exhibitions and collections in the museum) and people (museum staff, teachers, peers and families) complicates the learning process and is restrictive for researchers to carry out such research. However, as Salmi (1993) emphasizes, such environments are effective environments for increasing the interaction between school and society, providing students with opportunities to practice, observe, and increase their motivation.

The NHM use as an educational environment varies based on the subject studied. Mujtaba et al. (2018) described the literature on the role of NHM in increasing learning and supporting science education as complicated. This was expected because the NHMs are diverse, given that they have cultural objects, endemic species, geological structures, fossils, and formations specific to the country, region, city, or district they are situated in. This characteristic of NHM causes variety in studies in the field of science education. Gerber et al. (2001b) noted that as out-of-school activities are difficult to evaluate, they are generally not considered while evaluating students. They also emphasized that informal studies relying on museums are not researcher-friendly. Osborne and Dillon (2007) stated that research in formal settings is more common and how information is acquired in informal environments outside the school remains largely unclear. As can be understood from the literature, studies on museum education have quite different focuses. In addition, many studies also show promising results that museum visits affect students positively and contribute to their learning. However, there are limited studies related to creating a usable instruction program about education in museums, especially the effect of the program on the student. At this point, our study is designed to reveal how an instructional and organized museum environment will contribute to students and whether this instructional practice is suitable for use educational purposes. When the literature on museum education is examined, it is seen that museum education generally consists of pre-museum preparations, museum tours and post-museum evaluation processes (Buyurgan, 2019). It has been determined that the duration of the application at the stage of the museum visit, among the specified categories, varies according to the study group of the research, its variables and the focused context (Çıldır, 2018; Dilli et al., 2018; Egüz, 2020; Martin et al., 2016; Mortensen \& Smart, 2007; Türkmen, 2018). In the current research, only the science activities carried out during one day in the museum were evaluated within the scope of the relevant project. The study was conducted in the Ali Demirsoy Natural History Museum (ADNHM), which is one of the out-of-school learning environments, was the site for this study. This museum is unique because of its geographical location. Detailed information on this is presented in the Environment section. 


\section{Method}

The main problem of the study is that it evaluated the effects of science activities in natural history museums as out-of-school learning environments, on students' achievement, expectations/observations, feelings and learning experiences and to explore teachers' views about the process. The study relied on both quantitative and qualitative data collection and analyses and used a convergent parallel design (QUAL+quan) (Creswell \& Plano-Clark, 2015). In the current study, qualitative data were collected for the three sub-problems of the first research question (1a, 1b, 1c) and the second research problem, while for only the fourth sub-problem (1d), quantitative data were collected. As the research problems determined in the current study mainly required qualitative data, more qualitative methods and data collection tools were used. Thus, it is a qualitatively-dominated mixed study. Quantitative data were collected to understand the effect of the activities on the students' academic achievement. As the research problem mostly required qualitative data, more qualitative methods and data collection tools were used. Thus, it was a qualitatively-dominated mixed study.

The purpose of the research was to evaluate one-day science activities in natural history museums (ADNHM) as out-of-school learning environments through students' expectations, observations, feelings, learning experiences, and its effect on their academic achievement, and to explore teachers' views about the process. The subproblems are given below.

1. What are the expectations and learning experiences of the middle school students about the science activities conducted in the ADNHM?

a) What are the students' expectations and observations about the object (animate and inanimate entities) in the ADNHM before and after science activities?

b) What are the students' expectations and learning experiences about the science activities in the museum before and after?

c) What are the students' feelings about the ADNHM before and after the visit?

d) Have the science activities in the ADNHM had a quantitative effect on the students' academic achievement?

2. What are the teachers' views about the effect of the science activities on students in the ADNHM?

\section{Study Group}

The study group of the current research is comprised of middle school $5^{\text {th }}, 6^{\text {th }}$, $7^{\text {th }}$ and $8^{\text {th }}$ graders $(n=125)$ and eight teachers leading the instructional activities conducted in the museum. Four of the eight teachers leading the instructional activities in the museum had been in an out-of-school environment before. Service year of teachers [Teacher 1 (T1): 4 years, T2: 3 years, T3: 1 year, T4: 2 years, T5: 9 years, T6: 1 year, T7: 5 years, T8: 10 years] who participated the study range from one to 10 years and one of them male and seven of them female. The branches of the teachers participating in the research are science $(n=4)$, social studies $(n=2)$, music $(n=1)$ and physical education and sports $(n=1)$. 
Three data collection tools were administered to the middle school students in the study group. One of these tools is a multiple-choice achievement test, and two of them are semi-structured interview forms. The current research data were obtained within the scope of the project titled "A Scientific excursion in the natural history museum." 125 middle school students participated in the project training. As the administration of these data collection tools was on a volunteer basis, for the first and second semi-structured interview forms, 100 students were reached, and a total of 92 students were reached for the pre-test and post-test of the achievement test. The data about the participating students' state of being in an out-of-school environment was collected using the first semi-structured interview form. In this regard, it was found that $65(65 \%)$ of the participating 100 students had been in an out-of-school environment. Their responses in relation to the out-of-school trips they had participated in were analyzed by using content analysis to determine the characteristics of the study group. The students' responses were coded as follows: If a student participated in both the visit to the NHM and the trip to Kemaliye, frequency values were separately entered for them; thus the total number of students may vary.

Table 1

Themes and Codes in Relation to the Out-Of-School Environments that the Students Had Visited Before This Study

\begin{tabular}{|c|c|c|}
\hline Theme & Codes & $f$ \\
\hline Museum Visit & $\begin{array}{l}\text { Natural History Museum }(f=35) \text {, Ahmet Kutsi Tecer Museum }(f=8) \text {, } \\
\text { Ethnography Museum }(f=2) \text {, Topkapı Palace }(f=2) \text {, Toy Museum }(f=2) \text {, Halil } \\
\text { Tepe Museum }(f=1) \text {, Ali Kuşcu Science Centre }(f=1) \text {, Atatürk History } \\
\text { Museum }(f=1) \text {, Koç Museum }(f=1)\end{array}$ & 53 \\
\hline $\begin{array}{l}\text { City/Town/Villa } \\
\text { ge Trip }\end{array}$ & $\begin{array}{l}\text { Kemaliye }(f=10) \text {, Elazı } \breve{g}(f=8) \text {, Erzincan }(f=4) \text {, Apçağa Village }(f=3) \text {, } \\
\text { Aksaray }(f=1), \text { Kırkgöz }(f=1)\end{array}$ & 27 \\
\hline School Trip & Science High School $(f=3)$, University $(f=1)$. & 4 \\
\hline Others & Picnic $(f=5)$, Park $(f=4)$, Boat Trip $(f=3)$, Theatre $(f=1)$, Kite Festival $(f=1)$ & 14 \\
\hline Total & 22 Codes & 98 \\
\hline
\end{tabular}

It is seen that the majority of the students have been in out-of-school environments in Table 1. The out-of-school environments the students have been in include museums, cities, towns, school trips, picnics, theatre, kite festivals and boat trips. Most of the students have participated in a trip to a museum $(f=53)$. Yet, they have not received any training there.

\section{Data Collection Tools}

Four different data collection tools were used: a multiple-choice achievement test and two semi-structured interview forms for students, and a semi-structured interview form for teachers. The achievement test was applied as the pre and post tests to determine the students' academic achievement. The test had 14 multiple-choice questions (4 options) and was sent to 4 faculty members who are experts in the field in order to determine the content validity index. Based on the feedback received from the experts, four questions with negative content validity ratios were discarded. The test 
was piloted on 66 people, and its Cronbach Alpha reliability coefficient was .70. The maximum score that students can get from the achievement test is 10 .

A semi-structured interview form was prepared to identify the students' expectations and views before the science activities were implemented in the museum. Çalışkan and Çerkez (2012), Egüz and Kesten (2012), and Evren-Yapıcıoğlu et al. (2017) was used in the preparation of semi-structured interview form questions. The first part had a paragraph explaining the study and five questions (For example: What grade are you in? Have you ever taken a field trip before? Have you ever visited a museum before? etc.) to gather students' demographic information. The second part had three questions (For example: What do you hope to see at the NHM? What are your expectations? etc.) to gather data on the students' expectations. Second semi-structured interview form comprised eight questions (For example: What did you observe animate and inanimate in the NHM? What did you experience in the NHM?) to elicit data on the students' experiences after the science activities were complete.

The third semi-structured interview form was developed to gather data on the opinions of teachers on leading the students during the activities and the experiences of the students. The first part had a paragraph explaining the study and five questions to gather demographic information. The second part had five questions (For example: What did you observe in your students during the application process in the NHM? What are the observations and practices that interest you? Etc.) to gather data on the teachers' opinions on the students' experiences. All forms were reviewed by three experts who specialized in qualitative research and had experience and student-teacher interviews. Experts did not remove or add questions in the forms. They only made suggestions for better expression of some questions and corrections for spelling errors and structure of the forms. After corrections were made, the interviews forms were administered. While the student interview before the implementation of the science activities in the museum lasted 10 minutes, the interviews lasted between 15-20 minutes. Teacher interviews lasted 10 minutes.

\section{Data Analysis}

Analysis of the Qualitative Data: In the analysis of the qualitative data, the inductive content analysis method (Güler et al., 2015) was used, and manual coding was performed. The most important feature of the inductive content analysis method is that themes and categories are derived from the data at hand (Elo \& Kyngäs, 2008). A preliminary coding in light of the existing research was not performed. Some stages were followed in the data analysis process. At first, the raw data were transcribed into written text format consisted of sentences and paragraphs to make them ready for the analysis. The transcribed dataset was coded according to the research questions. By bringing similar codes together, sub-themes and themes were generated. A coding scheme was created by organizing sub-themes, themes and codes. The transcript, including the coding scheme and raw data, was sent to two experts specialized in qualitative analysis. The inter-coder reliability was calculated by using the formula proposed by Miles and Huberman (1994). The agreement between the coders was found to be $89 \%$. The last stage was to determine the codes repeated within the sub-themes and themes, and then they were turned into frequency tables and interpreted. 
Quantitative Data Analysis: In the analysis of the quantitative data, SPSS 22 program package was used. First, the data were entered into the program. Then assumptions were tested to decide the analysis techniques to be used. It is necessary to test the assumption of normality of the distribution to be able to use parametric statistical test techniques. The following three methods can be used to determine whether the data obtained for a continuous variable are distributed normally: skewness coefficient, mod, median and arithmetic mean. The descriptive characteristics of the quantitative data of the current study are given below.

Table 2

Pre- and Post-Tests' Descriptive Statistics Related to Quantitative Data

\begin{tabular}{lcccccccc}
\hline Test & Mean & Med & Var. & $S D$ & Min & Max & Skew & Kurt \\
\hline Pre-test & 3.90 & 4 & 1.97 & 1.40 & 1 & 7 & -.16 & -.45 \\
\hline Post-test & 5.73 & 6 & 3.31 & 1.82 & 0 & 10 & -.55 & .33 \\
\hline
\end{tabular}

As can be seen in Table 2, skewness and Kurtosis coefficients of the pre-test and post-test data are between -1 and +1 . Given that the sample size is larger than 30 , the distribution of the scores is accepted to be normal. As a result, paired sample t test, one of the parametric tests, was used to investigate the statistical significance between the pre-test and post-test scores.

Also effect size of Cohen's d (Cohen, 1988) is widely preferred for statistical methods (single group t-test, t-test for related samples, t-test for unrelated samples, etc.) in which the difference between the group mean is calculated (Özsoy \& Özsoy, 2013). The Cohen d coefficient was used to determine the effect size of the study and it is presented in the quantitative findings section.

\section{Context of the Study}

The study was conducted in the Prof. Dr. Ali Demirsoy Natural History Museum at Erzincan University in Kemaliye district, Erzincan. The museum has a total area of 1000 square meters and includes two large halls and conference rooms for 400 and 100 people, respectively, both of which are used for museum education. Natural specimens in the museum are geological materials like minerals, stones, soils, crystals, rocks, and fossil specimens. Another section displays exhibits of microscopic single-cell plants and animals living in the aquatic environment, invertebrates, crustaceans, and mollusks, which are placed in jars filled with alcohol solution. There are also plants in the herbarium, as well as mounted vertebrates from different parts of the country and the surrounding areas of Kemaliye.

\section{Procedures}

The current research data were obtained within the scope of the project titled " $A$ Scientific excursion in the natural history museum." The students in the study group of the current research participated in the one-day science activities carried out in the ADNHM in March $(n=32)$, April $(n=31)$, May $(n=32)$ and June $(n=30) 2019$ in groups. Prior to the instructional practices, a semi-structured interview form and the pre-test were administered to the students. Within the context of informal instructional practices, 
a total of six activities were carried out by faculty members specialized in their fields in the ADNHM. The brief contents of six activities are given below.

Table 3

Contents of Science Activities

Name and the Activity

1- Travel to 30 million years ago with fossils

2- I discover the plants

3-Microscopic life in a drop of water

4- I am touching insects
Content of the Activity

Before the activity, 30 fossil specimens within the museum, which are visible in size, were distributed and placed in a $150 \mathrm{~m}^{2}$ garden. Students were asked to find the fossil specimens they had seen in the museum and they had been given information about by searching in the garden having the same features with their natural environments and take one with them. While searching for the lost fossils, they were asked to think about how the species belonging to 30 million years ago could have survived to the present day, how these creatures living in the sea could be found at the top of the high mountains far from the sea, and to question the fossils by traveling to the past.

The students were allowed to examine more than 1000 plant species within the museum and the plant species grown in the culture medium with a microscope. Moreover, the students were presented with the techniques of keeping these culture plants as museum materials. Then each of the students was given a plant sample cultivated in the culture medium. The students were then informed on how to dry these plants in cartons and keep them intact, and then they were asked to prepare these plants in the same way.

Fixed water samples of the museum collected within the scope of different projects in the previous years were examined under the microscope.

In this activity, each student left a drop of water on the slide with a Pasteur pipette from the water samples and then covered it with the coverslip. Participants were asked to observe the single-celled creatures in the water by putting this preparation under a microscope, first finding the image from the smallest magnifying lens, and then moving to other large lenses for clarity. Each living thing they saw was examined together with their instructors. Discussions were conducted in a dynamic manner about which group it belongs to, its features and its importance in the ecosystem.

Insect samples in the exhibition and storage cabinets in the museum were distributed to the students. Each student was allowed to observe the samples with the help of a magnifying glass and a microscope. After the concerned expert gave the students the necessary information on how these insects are caught, a sweep net with an insect catching bucket was distributed to each student. The bugs caught with the buckets were rereleased without taking them. Later, one of the insect samples found in alcohol in the museum was placed in petri dishes and distributed to the students with forceps and needles. Each student was asked to examine it under a microscope. During the examinations, the instructors gave detailed information to the students about the insects' eyes, antennas, mouth structures, wings, legs, and abdomen parts.

The activity aimed to teach the relations of living groups in the ecosystem with each other and what kind of food web they were in, through interactive play. Each player took a card from a middle pile 
6. Traces from the Nature History Museum and raised it so that everyone could see the name of the organism on the card. The person who had drawn the tree card started the game by picking up the ball of twine and tossing it to someone else in the circle. The person who caught the ball tried to explain how the organism on their card interacted with the tree. Anyone in the group could join to help with this clarification. Next, the person who caught the ball grabbed the rope and tossed the ball to a third person. The third person explained how the organism on his card interacted with the second person's organism. If the player got stuck, everyone in the game could guess. The game continued until it is everyone had a chance to catch the twine. The string was now complex and tangled and everyone in the group was connected. Players could also discuss and exchange ideas about how their own organisms related to others that had appeared earlier in the game.

The activity tried to understand which of the phenomena students created in their own world regarding the museum came to the fore. During the activities held throughout the day, they had the opportunity to meet many living species from exhibition materials to the world of microscopes to mammals and gained experience about many living and non-living things that they had not seen, touched or felt before. Regarding the subject, they were given drawing paper, an eraser and a pencil, and they were asked to draw and explain what the museum meant to them.

\section{Ethical Procedures}

The current research data was obtained within the scope of the project titled "A Scientific excursion in the natural history museum." Ethics committee application and permission for the research was received from Hacettepe University on October 16, 2018 (numbered 35853172-900). Since the study group of the research was students under the age of 18, a parent permission form was used and obtained all the students who are participated in science activities in ADNHM. Students' responses to data collection tools for research are completely voluntary.

\section{Results}

\section{Qualitative Findings About the Students}

Two semi-structured interviews were conducted before and after the science activities were held at the museum. The students expressed that they expected to see some specimens in the interview conducted before the activities and preferred to talk about what they observed during the science activities in the interview that followed. The codes derived from these responses of the students are explained under the themes of expectations and observational experience of animate and inanimate entities and are presented in Table 4. 
Table 4

Students' Expectations and Observations of Animate and Inanimate Entities

\begin{tabular}{|c|c|c|c|c|c|c|}
\hline Themes & $\begin{array}{c}\text { Pre-activities } \\
\text { Codes } \\
\text { (Expected) }\end{array}$ & $\begin{array}{l}\text { The } \\
\text { Types of } \\
\text { Codes }\end{array}$ & $f_{\text {pre }}$ & $\begin{array}{c}\text { Post-activities Codes } \\
\text { (Observed) }\end{array}$ & $\begin{array}{l}\text { The Types } \\
\text { of Codes }\end{array}$ & $f_{\text {post }}$ \\
\hline $\begin{array}{l}\text { Geological } \\
\text { Structures } \\
\text { and Fossils }\end{array}$ & $\begin{array}{l}\text { Fossils }(f=28), \\
\text { Dinosaur } \\
\text { Skeleton }(f=9) \text {, } \\
\text { Bone }(f=5) \text {, } \\
\text { Stone }(f=10)\end{array}$ & 4 & 53 & $\begin{array}{l}\text { Fossils }(f=59), \text { Stones } \\
(f=16), \text { Rocks }(f=8), \\
\text { Lichens }(f=5), \text { Core of the } \\
\text { Earth }(f=3), \text { Minerals } \\
(f=1), \text { Magma }(f=1), \\
\text { Natural Disaster }(f=1) .\end{array}$ & 8 & 94 \\
\hline Vertebrates & $\begin{array}{l}\text { Animals }(f=31), \\
\text { Snake }(f=10), \\
\text { Fish }(f=3), \text { Deer } \\
(f=2), \text { Rain } \\
\text { Beetle }(f=2), \\
\text { Bird }(f=1), \\
\text { Turtle }(f=1), \\
\text { Gorilla }(f=1), \\
\text { Mammoth }(f=1)\end{array}$ & 9 & 52 & $\begin{array}{l}\text { Animals }(f=23), \text { Snake } \\
(f=16), \text { Wolf }(f=7), \text { Fish } \\
(f=7), \text { Leopard }(f=5), \text { Fox } \\
(f=5), \text { Grizzly Bear }(f=4), \\
\text { Bird }(f=4), \text { Goat }(f=2), \\
\text { Frog }(f=2), \text { Blowfish } \\
(f=2), \text { Mouse }(f=1), \text { Sea } \\
\text { Otter }(f=1), \text { Bee Eater } \\
(f=1), \text { Goose }(f=1), \\
\text { Wildcat }(f=1), \text { Yeanling } \\
(f=1), \text { Owl }(f=1), \text { Squirrel } \\
(f=1), \text { Eel }(f=1), \\
\text { Anatolian Leopard }(f=1), \\
\text { Deer }(f=1), \text { Dinosaur } \\
(f=1) .\end{array}$ & 23 & 89 \\
\hline Invertebrates & $\begin{array}{l}\text { Insect }(f=18), \\
\text { Butterfly }(f=5), \\
\text { Scorpion }(f=3), \\
\text { Spider }(f=1), \\
\text { Grasshopper } \\
(f=1), \\
\text { Caterpillar } \\
(f=1)\end{array}$ & 6 & 29 & $\begin{array}{l}\text { Insect }(f=65), \text { Butterfly } \\
(f=9), \text { Scorpion }(f=8), \\
\text { Mosquito }(f=6), \\
\text { Cockroach }(f=5), \text { Spider } \\
(f=5), \text { Fly }(f=4), \\
\text { Caterpillar }(f=4), \\
\text { Earthworm }(f=3), \text { Bee } \\
(f=3), \text { Sea Shell }(f=3), \\
\text { Starfish }(f=3), \\
\text { Grasshopper }(f=3), \text { Coral } \\
(f=2), \text { Lobster }(f=2), \\
\text { Mussel }(f=2), \text { Crustaceans } \\
(f=1), \text { Centipede }(f=1), \\
\text { Harvest Fly }(f=1)\end{array}$ & 19 & 130 \\
\hline Plants & Plants $(f=8)$ & 1 & 8 & $\begin{array}{l}\text { Flowers }(f=22), \text { Plants } \\
(f=11), \text { Tree }(f=2), \text { Tree } \\
\text { Root }(f=1), \text { Flower Liquid } \\
(f=1), \text { Flower Leaf }(f=1), \\
\text { Pollen }(f=1), \text { Reverse } \\
\text { Tulip }(f=1)\end{array}$ & 8 & 40 \\
\hline $\begin{array}{l}\text { Microscopic } \\
\text { Living } \\
\text { Things }\end{array}$ & $\begin{array}{l}\text { Microscopic } \\
\text { Living Things } \\
(f=7)\end{array}$ & 1 & 7 & $\begin{array}{l}\text { Microscopic Living } \\
\text { Things }(f=16), \text { Euglena } \\
(f=6), \text { Microorganisms } \\
(f=1), \text { Alga }(f=1), \\
\text { Microbe }(f=1), \text { Protozoa } \\
(f=1)\end{array}$ & 6 & 26 \\
\hline
\end{tabular}




\begin{tabular}{|c|c|c|c|c|c|c|}
\hline $\begin{array}{l}\text { Historical } \\
\text { Ruins }\end{array}$ & $\begin{array}{l}\text { Ruin }(f=6), \\
\text { Archaeology } \\
\text { History }(f=1), \\
\text { Historical } \\
\text { Artefact }(f=1), \\
\text { Historical } \\
\text { Natural Artefact } \\
(f=1) \text {, Historical } \\
\text { Weapon }(f=1)\end{array}$ & 5 & 10 & - & - & - \\
\hline Scientists & - & - & - & $\begin{array}{l}\text { Prof. Dr. Ali Demirsoy } \\
(f=3), \text { Scientist }(f=2), \\
\text { People from University } \\
(f=1), \text { Prof. Dr. Aydın } \\
\text { Akbulut }(f=1)\end{array}$ & 4 & 7 \\
\hline Others & $\begin{array}{l}\text { Poster }(f=1), \\
\text { Device }(f=1), \\
\text { Robot }(f=1), \\
\text { Animal } \\
\text { Drawing }(f=1)\end{array}$ & 4 & 4 & $\begin{array}{l}\text { Larva }(f=6), \text { Animal Skin } \\
(f=5), \text { Skeleton }(f=1), \\
\text { Goat Horn }(f=1), \text { Blood } \\
(f=1), \text { Herbarium }(f=1), \\
\text { Bark }(f=1)\end{array}$ & 7 & 16 \\
\hline Mushrooms & $\begin{array}{l}\text { Mushroom } \\
(f=1)\end{array}$ & 1 & 1 & Mushroom $(f=5)$ & 1 & 5 \\
\hline Total & & 31 & 164 & & 76 & 407 \\
\hline
\end{tabular}

As can be seen in Table 4, before and after the activities were conducted, the students had similar responses and more codes were derived from them. Only historical ruins in the scientist's pre- and post-activities did not have any code. A tangible increase was seen in the type and number of codes from the pre- (Types of codes: $31, f=164$ ) to post-test (Types of codes: $76 ; f=407$ ) stages. Before the activities were conducted, the students expected to see geological structures and fossils $(f=53)$, vertebrates $(f=52)$, and invertebrates $(f=29)$. After the activities were conducted, they stated that they had observed invertebrates $(f=130)$, geological structures and fossils $(f=94)$, and vertebrates $(f=89)$. The students described their expectations and experiences of the science activities in the ADNHM. Their responses are presented under four different sub-themes (observation and analysis, gains, others, and undescribed) in Table 5.

Table 5

Students' Expectations and Learning Experiences of the Science Activities

\begin{tabular}{llcc}
\hline Sub-themes & Codes & $f_{\text {pre }}$ & $f_{\text {post }}$ \\
\hline & Observing and analyzing different specimens & 31 & 16 \\
Observation and & Analyzing with a microscope & 6 & 23 \\
Analysis & Collecting and analyzing fossils & 2 & 20 \\
& Collecting and analyzing insects & - & 8 \\
& Learning different/new/unknown things & 17 & 11 \\
Gains & Getting to know and learn about living things in & 5 & 10 \\
& nature & &
\end{tabular}




\begin{tabular}{|c|c|c|c|}
\hline & Raising awareness of living things in nature & 1 & 4 \\
\hline & Learning how to use a microscope & - & 8 \\
\hline & Raising awareness of the formation of the earth & - & 5 \\
\hline & $\begin{array}{l}\text { Learning how herbariums and museums are } \\
\text { established }\end{array}$ & - & 2 \\
\hline Others & Planting trees & 2 & - \\
\hline Undescribed & Now knowing what to do & 5 & - \\
\hline Total & 12 Codes & 69 & 107 \\
\hline
\end{tabular}

According to the pre-test data, some students expected to engage in seven different instructional practices, whereas some did not know what to do $(f=5)$. However, a significant increase occurred in the type and number of the codes related to students' experiences compared to expectations in the post-test. Whereas the students expected to observe and analyze different specimens before activities, they talked about observations and experiences like conducting analyses with a microscope and collecting and analyzing fossils after activities. It is remarkable that microscope-related codes were distributed to two different codes and themes. Student statements are presented in Table 6 under different themes based on the emotions they felt before and after the activities were conducted.

Table 6

Emotions Felt by the Students Before and After the Activities Were Conducted

\begin{tabular}{lcc}
\hline Theme: Emotions & $f_{(\text {Pre })}$ & $f_{\text {(Post-) }}$ \\
\hline Happiness & 27 & 13 \\
Curiosity & 13 & 4 \\
Excitement & 12 & 3 \\
Beautiful & 12 & 24 \\
Nice & 4 & 4 \\
Enjoyable & 2 & 21 \\
Wonderful & 1 & 1 \\
Gratitude & - & 5 \\
Love & - & 4 \\
Interest & - & 4 \\
Stress reduction & - & 1 \\
Neutral & -11 & 1 \\
Bored & -1 & 86 \\
Total & & -1 \\
\hline
\end{tabular}

Students used 7 and 13 codes to express their feelings before and after the activities were conducted, respectively, as seen in Table 6 . The number of repeated 
codes increased. Students defined themselves as happy, curious, and excited about the activities at first. However, after the activities, the number of statements around satisfaction decreased, while that around enjoyment, beauty, and similar themes increased. They also expressed gratitude to the experts who helped them while conducting the activities.

\section{Quantitative Findings About The Students}

Paired samples t-test was conducted on the data from the achievement test and the findings are presented in Table 7 . There is a statistically significant difference between the achievement test mean scores from the pre- and post-tests' phases $\left[t_{(91)}=9.9, p<.05\right]$ as seen in Table 7 . The differences between the mean scores reached $31.93 \%$. These results show that the activities conducted at the museum had positive effects on the students' academic achievement.

\section{Table 7}

Paired Samples T-Test Conducted on the Pre-and Post-Tests' Scores Obtained from the Achievement Test

\begin{tabular}{lllllll}
\hline & $N$ & Mean & $S S$ & $S D$ & $t$ & $p$ \\
\hline Pre-test & 92 & 3.90 & 1.40 & 91 & -9.9 & .00 \\
Post-test & 92 & 5.73 & 1.82 & & & \\
\hline
\end{tabular}

Cohen $\mathrm{d}$ coefficient was calculated as .69 in the study. Since the Cohen $\mathrm{d}$ coefficient was between .2 and .8 (Cohen, 1988) as the effect size of the study, it was determined that it had a moderate effect.

\section{Qualitative Findings About the Teachers}

Through a semi-structured interview, teachers' opinions were elicited. The teachers were asked to record their observations of the students they accompanied. Eight codes were formed and are presented under two themes in Table 8.

Table 8

The Teachers' Views about the Effect of the Science Activities on the Students in the ADNHM

Theme 1: The effect of the Science Activities on Students Conducted at the Museum

Codes Quotations

Permanent Learning

T5: I think that the students were more active than they are in class and they achieved.

Active Participation

T8: In my opinion, the students were more active here and thus more permanent learning was accomplished.

Interest in Science T7: The students feeling like scientists were quite impressive.

Concrete Life

Experiences

T3: Students were able to attain concrete experiences.

Skill to Access

T8: They arrived at the information they needed without being 


\begin{tabular}{|c|c|}
\hline Information & perplexed by the large amount of theoretical information presented to them. \\
\hline $\begin{array}{l}\text { Environmental } \\
\text { Sensitivity }\end{array}$ & $\begin{array}{l}\text { T1: I think they were able to develop a different but more sensitive perception } \\
\text { of the environment. }\end{array}$ \\
\hline \multicolumn{2}{|c|}{ Theme 2: Students' Experiences during the instructional practice } \\
\hline $\begin{array}{l}\text { Observation and } \\
\text { Analysis }\end{array}$ & $\begin{array}{l}\text { T5: Students were provided opportunities that they could not otherwise access } \\
\text { in Kemaliye and thus, they conducted analyses. }\end{array}$ \\
\hline Using a Microscope & $\begin{array}{l}\text { T6: Students were interested in the details they had seen for the first time. } \\
\text { They were able to see through the microscope for the first time and gained } \\
\text { knowledge on how to use it. }\end{array}$ \\
\hline
\end{tabular}

Total: 8 Codes, 2 Themes

Note: $\mathrm{T}=$ Teacher

When Table 8 examined, the teachers accompanying the students thought that the science activities conducted at the museum fostered active student participation, enhanced their interest in science, helped them develop the skills they needed in order to have access to information, and improved their sensitivity toward the environment. They also stated that through the science activities conducted at the museum, the students learned to use a microscope and were engaged in observation and analysis.

\section{Discussion and Conclusion}

The purpose of the current study was to evaluate science activities in ADNHM as out-of-school learning environments through students' expectations, observations, feelings, learning experiences and its effect on their academic achievement, and to explore teachers' views about the process. Since the conceptual expressions of the students about the names of animate and inanimate entities in the museum collection have increased approximately two and a half times (The type of codes; $f_{\text {pre }}=31, f_{\text {post }}=76$; number of repeated codes; $\left.\mathrm{f}_{\text {pre }}=164 \mathrm{f}_{\text {post }}=407\right)$, the science activities conducted in the museum were found to have important contributions to the conceptual development of the students. When students presented the general name of the class or phylum of living things, such as plants, animals, insects etc., before the activities, they expressed the specific name of the species, genus, or ordo rather than upper taxonomic category names after activities as shown in Table 4 . The quantitative data obtained for the fourth sub-problem of the study revealed that the science activities conducted have positive effects on the learning of the students $\left[\mathrm{t}_{(91)}=-9.9, \mathrm{p}<.05\right]$. The Science activities in the NHM resulted in moderate effect in practice (Cohen $\mathrm{d}=.69$ ). As it is known, conceptual development is one of the first steps in the accomplishment of learning. It was expected because of the characteristics of an informal learning environment (Callanan et al., 2011; Marsick \& Volpe, 1999). The training in museums that allow using real and concrete materials help children to learn about a subject and perceive abstract concepts more easily depending on their cognitive development (Dilli et al., 2018). Similarly, Türkmen et al. (2016) are of the opinion that trips to informal learning environments such as NHM will contribute to students' classification of living things. The activities conducted in out-of-school environments like the museum in this study had a positive contribution to the students' conceptual development (Livingstone, 2006) and learning (Anderson et al., 2003; Gerber, et al., 2001a). The teachers participating in the current 
study are also of the opinion that the instructional activities conducted in the ADNHM "helped students be more active than they are in the class and achieve more permanent learning."

Before the activities were conducted, students expected to see geological structures and fossils rather than other specimens, and they talked more about their observations of invertebrates, geological structures, fossils, and vertebrates after the activities were conducted. The students expected to see more of the geological structures and fossils before the application because the activities in the current study would be made in a NHM and that students thought that they would see more inanimate components of nature such as fossils, stones and rocks. After the science activities in the museum, the students more frequently mentioned their observations about invertebrates using more code types. This might be because of the fact that these creatures were included more in the museum concept and that they have a much higher number of species in the world (Turkey Ministry of Forestry and Water Management, 2013) of living things. Another remarkable finding is that the students expressed expectations to see the objects normally exhibited in ethnography museums, such as historical ruins and historical weapons in the ADNHM. This might be because some of the participating students had visited ethnography museums before. In the theme of scientists emerging after completing the science activities, the students mentioned the names of the scientists involved in the practices, and thus, they observed. Involvement of faculty members from universities in such studies allowed the students to observe these scientists.

The results show that the students engaged in a different situation in the museum, which had gone beyond their expectations. The students' expectations and experiences of the science activities conducted in the ADNHM were collected under three subthemes. Before the activities were conducted, they mostly thought that they would observe or analyze something in the museum. According to Salmi (1993), students learn to observe and gain new experiences in such informal environments. The sub-themes and codes reached provide information about student experiences during the activities NHM, one of the out-of-school learning environments, and deepen the research. In the current study, while the students mentioned that they would perform actions such as observing and analysing living / non-living things before the application of the science activities, they mentioned that they carried out activities such as using a microscope and collecting and analysing fossils after the application of the instructional practices. According to this result, it can be said that the activities of "traveling to 30 million years ago with fossils" and "microscopic life in a drop of water" that students carried out during the informal science activities were interesting for them. In addition, the species belonging to the world of microscopic living things and fossils dating back to millions of years ago are living and non-living things drawing the students' interest. In their study, Green and Smith (2005) argued that small-sized things aroused great interest for primary school students and that the students' introduction to the microscope through the applications conducted by a primary school in cooperation with a university increased their interest in science and supported their success in science. As a result of the observations of the teachers who accompanied the students during the instructional practices, the codes related to the use of microscope and observation-analysis emerged. In addition, the fact that the variety and number of codes in the sub-theme of observing 
and analyzing is high can be interpreted as the science activities carried out in the museum contribute to the observation, classifications, predication skills, which are scientific process skills. When the studies in the literature are examined, it is stated that museum education for different participant groups than the current research improves the scientific process skills of the students (Bodur \& Y1ldırım, 2018; Öztürk Samur et al., 2015). In addition, similar results were reached in studies in which more than one area (one of them was museum) and different participant group was used for out-ofschool learning environments (Uludağ, 2017).

Students' emotions pertaining to the activities conducted were the most interesting outcomes. They expected to engage in an out-of-school activity in a museum for which they were not responsible as in school. However, the activities in the museum comprised an instructed program. It was different from what the students engaged with at school and it took place in an environment outside of school. Thus, they were happy, curious, and excited about the activities before visiting the museum. These feelings gave place to feelings of enjoyment and appreciation for beauty after the activities were conducted. Appreciation of beauty and enjoyment are more objective and tangible. Anderson and Lucas (1997) noted that curiosity is a stimulus that helps one explore, manipulate, and interact with the environment and is generated by the individual's feelings of perceived novelty. The results show that the activities satisfied students' curiosity after the program was conducted. McManus (1987) suggested that a part of the reason for visiting a public education facility is the anticipation of enjoyable social interaction. Visits to museums are enjoyable social events (Anderson, 1999). This is partly because visitors expect to enjoy the social context (Falk \& Dierking, 1992, 1997). Out-of-school environments enhance student interest in topics like biology (Uitto et al., 2006) and effectively increase their motivation (Shoshani \& Eldor, 2016). Whereas only two students stated that the activities were enjoyable before visiting the museum, the number increased to 21 after the activities were conducted. The reason for the increase was that activities in the museum, as shown in Table 2, involved social interactions among the students and between students and instructors. Low happiness and excitement on the part of students in the beginning may explain that they did not have any expectations pertaining to the museum experience. They expected to visit the museum and walk around. In addition to this, students were tired due to participating in activities all day. This may be another reason for the decreased happiness and excitement after the activities.

Teachers were also of the view that activities in the museum "helped students become more active than they were in class and to achieve more permanent learning." Thus, it can be argued that such practices can have positive effects on students' learning outcomes. Sontay et al. (2016) concluded that science teaching carried out in out-ofschool environments can make students' learning more permanent and can provide students with effective and enjoyable means of learning. Some qualitative codes derived from the teachers' opinions are explained above in relation to student learning outcomes. The teachers thought that the instructional practices conducted at the museum fostered active student participation, enhanced their interest in science, helped them develop the learning skills they needed in order to gain access to information, improved their sensitivity toward the environment, and helped them accomplish more permanent learning. They stated that in informal instructional practices conducted at the museum, 
students were engaged in observation and analysis with the use of a microscope. Storksdieck (2001) examined the museum experiences of teachers and students and stated that teachers had a different experience of the educational trip to the museum, as they came with far more knowledge and awareness than their students.

\section{Implications}

Activities conducted in museums for middle school students seem to be effective in enhancing their conceptual development and learning. These activities can be more expansive by including different student groups, such as high school and university students, to improve their knowledge of the classification of living and non-living things and different branches of science such as taxonomy and gain experience by making observations. Aside from museums, university laboratories, campuses, and workshops that can increase students' interaction with scientists can be used to conduct such activities.

Museums globally serve all the people, but they also carry the special characteristics of the country, region, or district that they are set in because of the things they exhibit. Student observations and experiences in NHM in different regions and districts can be examined in this respect. It motivated the students to participate in instructional activities and discover different objects and people outside school. Education in a museum is not very difficult in terms of access to space and resources. However, the problem is the lack of qualified instructors and teachers. Different experts from universities helped conduct activities as instructors in this study. Most museums in Turkey do not have special education programs and instructors. Museums with special education programs in other countries in Europe are also limited in number. In this respect, we suggest that museums offer an effective learning environment for students and other people.

\section{Acknowledgments}

This study was funded by TÜBİTAK (Scientific and Technological Research Council of Turkey) under grant (218B189). To carry out the study, necessary permissions were obtained from the Ethics Boards and Commission of Hacettepe University and the Ministry of Education.

\section{Statement of Responsibility}

The authors contributed equally to the related research. Therefore, each author is equally responsible.

\section{Conflicts of Interest}

This research has no financial, commercial, legal or professional relationship with other organizations or those working with them. There is no conflict of interest that would affect the research. 


\section{References}

Anderson, D. (1999). The development of science concepts emergent from science museum and post-visit activity experiences: students' construction of knowledge [Unpublished doctoral dissertation]. Queensland University of Technology.

Anderson, D., \& Lucas, K. B. (1997). The effectiveness of orienting students to the physical features of a science museum prior to visitation. Research in Science Education, 27(4), 485-495. https://doi.org/10.1007/BF02461476

Anderson, D., Lucas, K. B., \& Ginns, I. S. (2003). Theoretical perspectives on learning in an informal setting. Journal of Research in Science Teaching, 40(2), 177-199. https://doi.org/10.1002/tea.10071

Anderson, D., Piscitelli, B., Weier, K., Everett, M., \& Tayler, C. (2002). Children's museum experiences: identifying powerful mediators of learning. Curator: The Museum Journal, 45(3), 213-231. https://doi.org/10.1111/j.21516952.2002.tb00057.x

Andre, L., Durksen, T., \& Volman, M. L. (2017). Museums as avenues of learning for children: a decade of research. Learning Environmental Research, 20(1), 47-76. https://doi.org/10.1007/s10984-016-9222-9

Atmaca, S. (2012). Derslik dışı fen etkinlikleri ve bu etkinliklere dayalı ögretimin ögretmen adaylart üzerindeki etkileri [Outdoor education activities in science education and effects of these activities on pre-service teachers] [Unpublished doctoral dissertation]. Hacettepe University.

Ay, Y., Anagün, Ş. S., \& Demir, Z. M. (2015). Sınıf öğretmeni adaylarının fen öğretiminde okul dişı öğrenme hakkındaki görüşleri [Pre-service primary school teachers' opinions about out-of-school learning in science teaching]. Turkish Studies, 10(15), 103-118. http://dx.doi.org/10.7827/TurkishStudies.8702

Ayres, R., \& Melear, C. T. (1998). Increased learning of physical science concepts via multimedia exhibit compared to hands-on exhibit in a science museum. Annual Meeting of National Association for Research in Science Teaching. San Diego, CA.

Bodur, Z., \& Yıldırım, M. (2018). Sınıf dışı etkinliklerinin ortaokul yedinci sınıf öğrencilerinin akademik başarıları ve bilimsel süreç becerileri üzerine etkisi [The effect of outdoor activities on academic achievement and scientific process skills of 7th students in secondary school]. Marmara Üniversitesi Atatürk Eğitim Fakültesi Eğitim Bilimleri Dergisi, 47(47), 125-140.

Bontempi, E., \& Smith Nash, S. (2012). Effective strategies in museum distance education. http://proceedings.informingscience.org/InSITE2012/InSITE12p013025Bontempi0008.pdf

Bostan Sarıŏlan, A., \& Küçüközer, H. (2017). Fen bilgisi öğretmen adaylarının okul dışı öğrenme ortamları ile ilgili görüşlerinin araştırılması [Investigation of preservice science teachers' opinions regarded to outdoor school learning environments]. Informal Ortamlarda Araştırmalar Dergisi, 2(1), 1-15.

Bulut, P., \& Uzun, E. B. (2021). Sanal müzeler ve yaratıcı drama için bir atölye önerisi: müze sinifa geliyor!. [A workshop proposal for virtual museums and creative drama: museum comes to class!]. Yaratıcı Drama Dergisi, 16(1), 131-156. 
Buyurgan, S. (2019). Müze eğitimi: Öğrenme ortamı olarak müzeler [Museum education: Museums as learning environment]. Pegem Akademi.

Çalışkan, H., \& Çerkez, S. (2012). An evaluation of education with museum practices in social studies classes based on student views. International Online Journal of Educational Sciences, 4(1), 162-173

Callanan, M., Cervantes, C., \& Loomis, M. (2011). Informal learning. Wiley Interdisciplinary Reviews: Cognitive Science, 2(6), 646-655. https://doi.org/10.1002/wcs.143

Çıldır, B. (2018). Müzede eğitim etkinliklerinin öğrencilerin yazma becerilerine etkisi [The effect of learning in museum activities upon the writing skills of students]. Ankara Üniversitesi Eğitim Bilimleri Fakültesi Dergisi, 51(3), 19-44.

Cohen, J. (1988). Statistical power analysis for the behavioral sciences (2 ${ }^{\text {nd }}$ ed.). Lawrence Erlbaum Associates Publishers.

Cox-Petersen, A. M., Marsh, d. D., Kisiel, J., \& Melber, L. M. (2003). Investigation of guided school tours, student learning, and science reform recommendations at a museum of natural history. Journal of Research in Science Teaching, 40(2), 200218. https://doi.org/10.1002/tea.10072

Creswell, J. W., \& Plano-Clark, V. L. (2015). Karma yöntem araştırmaları: Tasarımı ve yürütülmesi [Designing and conducting mixed methods research]. Translated by Y. Dede and S. B. Demir. Anı Publishing.

Dilli, R., Bapoğlu Dümenci, S., \& Turgut Kesebir, G. (2018). Müzede çevre eğitimi kapsamında okul öncesi dönemi çocuklarına yenilenebilir enerji kaynaklarının anlatılmas1 [Discussion of renewable energy resources for pre-school children within in the scope of museum environmental education]. Elektronik Sosyal bilimler Dergisi, 17(66), 421-432. https://doi.org/10.17755/esosder.319406

Dragotto, E., Minerva, C., \& Nichols, M. (2006). Is museum education 'rocket science'?. Journal of Museum Education, 31(3), 215-222. https://doi.org/10.1080/10598650.2006.11510548

EGMUS. (2020). The european group on museum statistics 2020. https://www.egmus.eu.

Egüz, Ș. (2020). Sosyal bilgiler dersinde müze eğitim uygulamalarının öğrencilere etkisi [The effect of museum education applications on students in social studies course]. Milli Eğitim Dergisi, 49(227), 245-270.

Egüz, Ş., \& Kesten, A. (2012). Sosyal bilgiler dersinde müze ile eğitimin öğretmen ve öğrenci görüşlerine göre değerlendirilmesi: Samsun ili örneği [Teachers and students' opinions regarding learning with museum in social studies course: Case of Samsun]. İn̈nü Üniversitesi Eğitim Fakültesi Dergisi, 13(1), 81-103

Elo, S., \& Kyngäs, H. (2008). The qualitative content analysis process. Journal of Advanced Nursing, 62(2), 107-115. https://doi.org/10.1111/j.13652648.2007.04569.x

Eshach, H. (2007). Bridging in-school and out-of-school learning: Formal, non-formal, and informal education. Journal of Science Education and Technology, 16(2), 171190. https://doi.org/10.1007/s10956-006-9027-1 
Evren-Yapıcıoğlu, A., Atmaca, S., Akbulut, A., Ceyhan, G. D., Durmuş, Y., Akaydın, G., \& Demirsoy, A. (2017). Journey to natural history museum in perspective of children. European Journal of Science and Mathematics Education, 5(4), 365-375. https://eric.ed.gov/?id=EJ1279946

Falk, J. H. (2005). Free-choice environmental learning: Framing the discussion. Environmental Education Research, 11(3), 265-280. https://doi.org/10.1080/13504620500081129

Falk, J. H., \& Dierking, L. D. (1992). The Museum experience. Washington Howells House.

Falk, J. H., \& Dierking, L. D. (1997). Assessing their long-term impact. Curator: The Museum Journal, 40(3), 211-218. https://doi.org/10.1111/j.21516952.1997.tb01304.x

Gerber, B. L., Cavallo, A. M. L., \& Marek, E. A. (2001a). Relationships among informal learning environments, teaching procedures and scientific reasoning ability. International Journal of Science Education, 23(5), 535-549. https://doi.org/10.1080/09500690116971

Gerber, B. L., Marek, E. A., \& Cavallo, A. M. L. (2001b). Development of an informal learning opportunities assay. International Journal of Science Education, 23(6), 569-587. https://doi.org/10.1080/09500690116959

Green, S., \& Smith, J. (2005). Small things draw big interest. Science and Children 42(4), 30 .

Griffin, J. (2004). Research on students and museums: looking more closely at the students in school groups. Science Education, 88(1), 59-70. https://doi.org/10.1002/sce.20018

Güler, A., Halıcıoğlu, B. M., \& Taşğın, S. (2015). Sosyal bilimlerde nitel araştırma yöntemleri [Qualitative research methods in the social sciences]. Seçkin Press.

Hofstein, A., \& Rosenfeld, S. (1996). Bridging the gap between formal and informal science learning. Studies in Science Education, 28(1), 87-112. https://doi.org/10.1080/03057269608560085

Karadeniz, C. (2020). The use of digital technologies in the museum and digital participation through pandemic process. IDIL, Journal of Art and Language, 70, 975-984. https://doi.org/10.7816/idil-09-70-06

Kasapoğlu Akyol, P. (2020). Covıd-19 Küresel salgın dönemi ve sonrası müze etkinlikleri [Museum activities during and after the Covid-19 pandemic]. Milli Folklor, 16(127), 72-86.

Kisiel, J. F. (2003). Teachers, museums and worksheets: a closer look at a learning experience. Journal of Science Teacher Education, 14(1), 3-21. https://doi.org/10.1023/A:1022991222494

Klopfer, E., Perry, J., Squire, K., Jan, M. F., \& Steinkuehler, C. (2005). Mystery at the museum-a collaborative game for museum education. In Proceedings of the International Conference on Computer Supported Collaborative Learning edited by T. Koschmann, D. D. Suthers, and T. Chan, 316-320. International Society of the Learning Sciences. 
Koran, J. J., \& Koran, M. L. (1986). A Proposed framework for exploring museum education research. The Journal of Museum Education, 11(1), 12-16.

Kubota, C. A., \& Olstad, R. G. (1991). Effects of novelty-reducing preparation on exploratory behavior and cognitive learning in a science museum setting. Journal of Research in Science, 28(3), 225-234.

Laherto, A. (2013). Informing the development of science exhibitions through educational research. International Journal of Science Education, 3(2), 121-143. https://doi.org/10.1080/21548455.2012.694490

Livingstone, D. W. (2006). Informal learning: Conceptual distinctions and preliminary $\begin{array}{lll}\text { findings. } & \text { Counterpoints, } & 249,\end{array}$ https://www.jstor.org/stable/pdf/42979596.pdf

Marsick, V. J., \& Volpe, M. (1999). The nature and need for informal learning. Advances in Developing Human Resources, 1(3), 1-9. https://doi.org/10.1177/152342239900100302

Martin, A. J., Durksen, T. L., Williamson, D., Kiss, J., \& Ginns, P. (2016). The role of a museum-based science education program in promoting content knowledge and science motivation. Journal of Research in Science Teaching, 53(9), 1364-1384. https://doi.org/10.1002/tea.21332

McManus, P. M. (1987). It's the company you keep...: The social determination of learning-related behaviour in a science museum. Museum Management and Curatorship, 6(3), 263-270. https://doi.org/10.1080/09647778709515076

Melton, A., Feldman, N. G., \& Mason, C. W. (1936). Experimental Studies of the Education of Children in a Museum of Science. https://files.eric.ed.gov/fulltext/ED044929.pdf

Miles, M. B., \& Huberman, M. (1994). Qualitative data analysis: An expanded sourcebook. SAGE.

Mortensen, M. F., \& Smart, K. (2007). Free-choice worksheets increase students' exposure to curriculum during museum visits. Journal of Research in Science Teaching, 44(9), 1389-1414. https://doi.org/10.1002/tea.20206

Mujtaba, T., Lawrence, M., Oliver, M., \& Reiss, M. J. (2018). Learning and engagement through natural history museums. Studies in Science Education, 54(1), 41-67. https://doi.org/10.1080/03057267.2018.1442820

Notario Sánchez, Á. (2020). From the public museum to the virtual museum. Communication in the museum in digital environments. Socializing Art Museums, edited by Alejandra Alonso Tak and Ángel Pazos-López. De Gruyter https://doi.org/10.1515/9783110662085-005

Osborne, J., \& Dillon, J. (2007). Research on learning in informal contexts: Advancing the field?. International Journal of Science Education, 29(12), 1441-1445. https://doi.org/10.1080/09500690701491122

Özsoy, S., \& Özsoy, G. (2013). Effect size reporting in educational research. Elementary Education Online, 12(2), 334-346.

Öztürk Samur, A., Kocyiğit, S., İnci, E., Aydoğan, S., \& Basara Baydilek, N. (2015). Impact of museum education on 60-72 months' children's scientific processing 
skills, social skills and perception of museum. International Journal of Academic Research, 7(2), 231-236.

Piscitelli, B., \& Anderson, D. (2001). Young children's perspectives of museum settings and experiences. Museum Management and Curatorship, 19(3), 269-282. https://doi.org/10.1080/09647770100401903

Rennie, L. J. (1994). Measuring affective outcomes from a visit to a science education centre. Research in Science Education, 24(1), 261-269. https://doi.org/10.1007/BF02356352

Rennie, L. J., \& McClafferty, T. P. (1996). Science centers and science learning. Studies in Science Education, 27(1), 53-98. https://doi.org/10.1080/03057269608560078

Rogoff, B., Callanan, M., Gutiérrez, K. D., \& Erickson, F. (2016). The organization of informal learning. Review of Research in education, 40(1), 356-401. https://doi.org/10.3102/0091732X16680994

Salmi, H. (1993). Science centre education: Motivation and learning in informal education. https://files.eric.ed.gov/fulltext/ED363613.pdf.

Shaby, N., Assaraf, O. B. Z., \& Tishler, C. E. (2016). The goals of science museums in the eyes of museum pedagogical staff. Learning Environments Research, 19(3), 359-382. https://doi.org/10.1007/s10984-016-9211-z

Shoshani, A., \& Eldor, L. (2016). The Informal learning of teachers: learning climate, job satisfaction and teachers' and students' motivation and well-being. International Journal of Educational Research, 79, 52-63. https://doi.org/10.1016/j.ijer.2016.06.007

Solmaz, K. (2015). Sosyal bilgiler öğretmenlerinin müze eğitimine yönelik görüşleri ve uygulamalar1 [Opinions and applications of social science teacher for the museum education]. Munzur Üniversitesi Sosyal Bilimler Dergisi, 4(7), 40-54.

Sontay, G., Tutar, M., \& Karamustafaoğlu, O. (2016). Okul dışı öğrenme ortamları ile fen öğretimi hakkındaki öğrenci görüşleri: Planetaryum gezisi [Student views about "science teaching with outdoor learning environments": Planetarium tour]. Informal Ortamlarda Araştırmalar Dergisi, 1(1), 1-24.

Storksdieck, M. (2001). Differences in teachers' and students' museum field-trip experiences. http://kora.matrix.msu.edu/files/31/173/1F-AD-4C-8-VSA-a0a6t7a_5730.pdf

Suter, L. E. (2014). Visiting science museums during middle and high school: a longitudinal analysis of student performance in science. Science Education, 98(5), 815-839. https://doi.org/10.1002/sce.21116

Tal, R., Bamberger, Y., \& Morag, O. (2005). Guided school visits to natural history museum in Israel: Teachers' role. Science Education, 89(6), 920-935. https://doi.org/10.1002/sce.20070

Taranova, T. N. (2020). Virtual museum technologies and the modern educational process. VI. International Forum on Teacher Education, Proceedings IFTE-2020, 2513-2521. https://doi.org/10.3897/ap.2.e2513

Taylor, E. W., \& Neill, A. C. (2008). Museum Education. Journal of Museum Education, 33(1), 23-32. https://doi.org/10.1080/10598650.2008.11510584 
The Ministry of Culture and Tourism. (2020). Accessed November 25, 2020. https://www.ktb.gov.tr

Tuan Soh, T. M., \& Mohd Meerah, T. S. (2013). Outdoor Education: An Alternative Approach in Teaching and Learning Science. Asian Social Science, 9(16), 1-8. https://doi.org/10.5539/ass.v9n16p1

Turkey Ministry of Forestry and Water Management. (2013). Biyokaçakçılıkla mücadele rehberi. http://www.nuhungemisi.gov.tr/Content/Documents/biyokacakcilikla-mucadelerehberi.pdf

Türkmen, H. (2018). İnformal öğrenme ortamının fosiller konusunun öğrenilmesine etkisi: tabiat tarihi müzesi örneği [The effect of informal learning environment on the learning of fossils: case of the natural history museum]. Afyon Kocatepe Üniversitesi Sosyal Bilimler Dergisi, 20(3), 137-147. https://doi.org/10.32709/akusosbil.417266

Türkmen, H., Topkaç, D. D., \& Atasayar Yamık, G. (2016). İnformal öğrenme ortamlarına yapılan gezilerin canlıların sınıflandırılması ve yaşadığımız çevre konusunun öğrenilmesine etkisi: tabiat tarihi müzesi ve botanik bahçesi örneği [The effect of field trips to informal learning environment on learning of "classification of living things": case of the natural history museum and botanical]. Ege Ĕgitim Dergisi, 17(1), 174-197.

Uitto, A., Juuti, K., Lavonen, J., \& Meisalo, V. (2006). Students' interest in biology and their out-of-school experiences. Journal of Biological Education, 40(3), 124-129. https://doi.org/10.1080/00219266.2006.9656029

Uludağ, G. (2017). Okul dışı öğrenme ortamlarının fen eğitiminde kullanılmasının okul öncesi dönemdeki çocukların bilimsel süreç becerilerine etkisi [The effect of using out-of-school learning environments for science education on preschool children's science process skills (Unpublished doctoral dissertation)]. Hacettepe University.

Wolins, I. S., Jensen, N., \& Ulzheimer, R. (1992). Children's memories of museum field trips: a qualitative study. Journal of Museum Education, 17(2), 17-27. https://doi.org/10.1080/10598650.1992.11510204

Yetkiner, A., Karadeniz, C., \& Çıldır Gökaslan, Z. (2019). "No student not met museum education" a practice of volunteer education program in the museum. Journal of Education and Future, 16, 79-91. https://doi.org/10.30786/jef.468074

This is an Open Access article distributed under the terms of the Creative CommonsAttributionNonCommercial-ShareAlike 4.0 International (CC BY-NC-SA 4.0). For further information, you can refer to https://creativecommons.org/licenses/by-nc-sa/4.0/ 